Antje Wichels • Christian Hummert •

Malte Elbrächter - Bernd Luckas • Christian Schütt •

Gunnar Gerdts

\title{
Bacterial diversity in toxic Alexandrium tamarense blooms off the Orkney Isles and the Firth of Forth
}

Published online: 6 May 2004

(C) Springer-Verlag and AWI 2004

\section{Helgoland Marine Research (2004) s10152-004-0174-6}

The address of Malte Elbrächter should be as given above.

The Introduction should begin with the following sentence:

Populations of Alexandrium tamarense around the Orkney Islands produce potent neurotoxins, paralytic shellfish poisoning (PSP) toxins (Medlin et al. 1998).
The online version of the original article can be found at http://dx.doi.org/10.1007/s10152-004-0174-6

A. Wichels $(\bullet) \cdot$ C. Schütt · G. Gerdts

Alfred-Wegener-Institut für Polar- und Meeresforschung,

Biologische Anstalt Helgoland,

27483 Helgoland, Germany

e-mail: awichels@awi-bremerhaven.de

Tel.: +49-4725-819245

Fax: +49-4725-819283

C. Hummert

Chemical and Biological Analyses, WEJ GmbH,

21107 Hamburg, Germany

M. Elbrächter

Deutsches Zentrum für Biodiversitätsforschung,

FI-Senckenberg, Wattenmeerstation Sylt,

Hafenstrasse 43, 25992 List/Sylt, Germany

B. Luckas

Department of Biology and Pharmacy,

Institute of Food Chemistry, Friedrich-Schiller-University Jena,

07743 Jena, Germany
The following reference should be included:

Medlin LK, Lange M, Wellbrock U, Donner G, Elbrächter M, Hummert C, Luckas B (1998) Sequence comparisons link toxic European isolates of Alexandrium tamarense from the orkney Islands to toxic North American stocks. Eur J Protistol 34:329-335 